\title{
Congress may threaten NIH autonomy
}

\section{Washington}

FEARS for the political independence of the National Institutes of Health have once again come to the surface. The cause of the trouble is a Bill now working its way through the House of Representatives that would require that the several institutes of the NIH are funded individually by Congress.

The scientific community is alarmed that the proposed arrangements would enable Congress - or individual congressmen to attach unworkable provisions to financial legislation. Meanwhile, the administrators of the NIH have drawn the wrath of their political bosses at the Department of Health and Human Services (previously Health, Education and Welfare) by their attempts to head off the legislation in its earlier stages.

At one stage, it is widely reported, the Director of the NIH, Dr Donald Fredrickson, was told by the Secretary of DHHS, Mrs Pat Harris, to "shut up or get out". Dr Fredrickson has stayed put.

Relations between the NIH and its sponsoring department have never been easy. On this occasion, however, the House Bill may seem a lesser evil than a similar piece of legislation introduced in the Senate last year by Senator Edward Kennedy, chairman of the Senate Health and Science Subcommittee.

Kennedy's Bill would make all the institutes of the NIH separately accountable to Congress, but would also have imposed several other unpalatable conditions on the planning of medical research. One of these persists in the version of the Kennedy Bill soon to be considered by the Senate - the proposal that $\mathrm{NIH}$ strategy should be determined by a sixteen-member council appointed by the President.

\section{Waxman proposes}

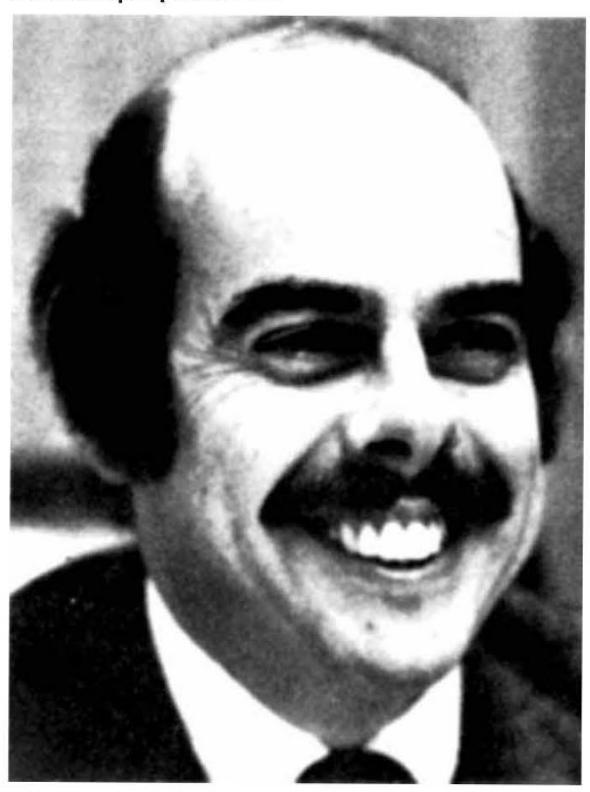

The Administration is staunchly opposed to this condition, but appears ready to accept that separate accountability will in future be required of the institutes. This position appears to have been reached only after an acrimonious dispute within the DHHS, where Mrs Harris was at first strongly opposed to some aspects of the House Bill.

The chief consequences of the Bill as it stands will be budgetary. (Two of the eleven institutes of the NIH, the National Cancer Institute and the National Heart, Lung and Blood Institute, are already dealt with separately in Congress.)

Budget strategy will be approved on a three-year basis, with a provision that

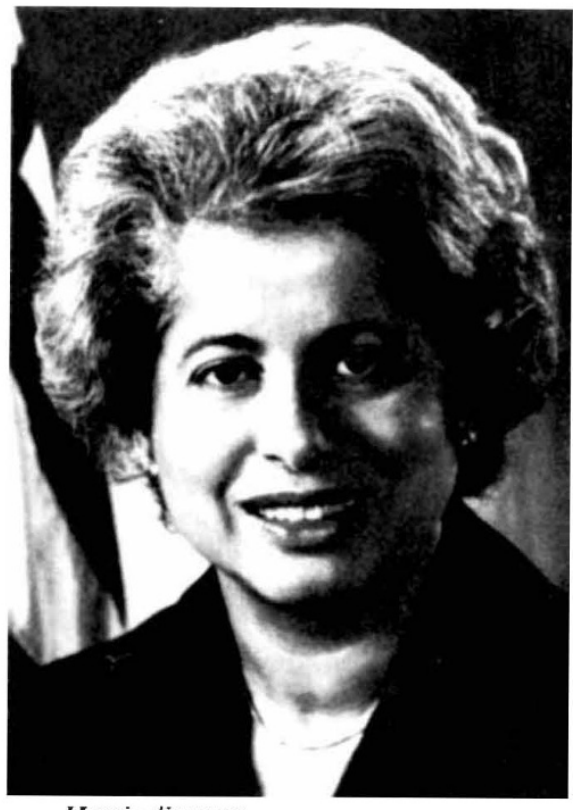

Harris disposes

spending may be continued for a fourth year if Congress fails to act. Representative Henry Waxman, chairman of the Health Subcommittee, says however that there is no intention of using the new legislation as a way of cutting individual institute budgets, which will in any case be protected by separate appropriations legislation.

In spite of Mrs Harris's wrath, the NIH have won some concessions from the House of Representatives. A limit on the amount of research grant that could be approved by an individual institute council has been increased from $\$ 50,000$ to $\$ 500,000$. Moreover, there is a new provision for a fund of $\$ 100$ million to be spent on areas considered by the Director of NIH to be especially deserving of support.

NIH officials are still unhappy, however, with the increased role of externally appointed advisory committees in the planning of research strategy, while the extent to which the Secretary of DHHS may delegate responsibilities to the Director is, it appears, to be on the Secretary's say so.
Both the Senate and House bills are likely soon to pass in their respective chambers. In the conference that follows, it should become clear in what corner Mrs Secretary Harris is fighting.

David Dickson

\section{Marine Pollution}

\section{Clean the Med}

ELEVEN Mediterranean nations signed a treaty in Athens last Saturday (17 May) which commits them to clean up their rivers and sewage discharges, to make the Mediterranean a fit place to swim and fish in again. At present 90 per cent of the sewage from the 120 largest Mediterranean cities is poured into the sea untreated; and Italy, France and Spain sweep out their industrial pollutants through the rivers $\mathrm{Po}$, Rhône and Ebro. Effective control of these land-based sources - the objective of the treaty - will cost some $£ 6$ billion, it is estimated. But 100 million tourists a year and a $£ 300$ million fishing industry will benefit.

The treaty is the sweetest fruit so far of the United Nations Environment Programme's Regional Seas Programme, which is run by Yugoslav marine scientist Dr Stjepan Keckes. He takes an optimistic view. "The British began talking about cleaning up the Thames 25 years ago. Today, salmon have returned to the Thames. I believe we can make the Mediterranean a much cleaner and safer place by the end of this decade."

The foundation of the treaty is both scientific and political: a network of laboratories around the Mediterranean coasts, many of whose staff have been trained and equipped through the Regional Seas Programme. Keckes has insisted on establishing uniform measurement procedures, and has used national laboratories (rather than a single, international expert team) to ensure the respect of national governments for their data. Keckes has also aimed the programme largely towards the definition of 'water quality objectives' rather than uniform emission standards; this has the advantage that, say, the relatively undeveloped North African coast can initially accept higherpolluting factories simply because there are fewer of them - so development is not penalised. The main burden will in fact fall on Italy, France and Spain.

The treaty will have to be ratified by six nations before it comes into force. Ratification would follow the passing of the necessary national legislation.

Two classes of pollutant are defined in the treaty: 'black list' and 'grey list' substances. Black list substances will be limited to very low emissions, because of their toxicity, persistence, or accumulation 